IZA DP No. 4924

Macroeconomic Volatilities and the Labor Market: First Results from the Euro Experiment

Christian Merkl

Tom Schmitz

May 2010 


\title{
Macroeconomic Volatilities and the Labor Market: First Results from the Euro Experiment
}

\author{
Christian Merkl \\ IfW Kiel, Christian Albrechts University \\ and IZA \\ Tom Schmitz \\ HEC Paris, Sciences Po \\ and IfW Kiel
}

Discussion Paper No. 4924

May 2010

IZA

P.O. Box 7240

53072 Bonn

Germany

Phone: +49-228-3894-0

Fax: +49-228-3894-180

E-mail: iza@iza.org

\begin{abstract}
Any opinions expressed here are those of the author(s) and not those of IZA. Research published in this series may include views on policy, but the institute itself takes no institutional policy positions.

The Institute for the Study of Labor (IZA) in Bonn is a local and virtual international research center and a place of communication between science, politics and business. IZA is an independent nonprofit organization supported by Deutsche Post Foundation. The center is associated with the University of Bonn and offers a stimulating research environment through its international network, workshops and conferences, data service, project support, research visits and doctoral program. IZA engages in (i) original and internationally competitive research in all fields of labor economics, (ii) development of policy concepts, and (iii) dissemination of research results and concepts to the interested public.
\end{abstract}

IZA Discussion Papers often represent preliminary work and are circulated to encourage discussion. Citation of such a paper should account for its provisional character. A revised version may be available directly from the author. 


\section{ABSTRACT}

\section{Macroeconomic Volatilities and the Labor Market: First Results from the Euro Experiment ${ }^{*}$}

This paper analyzes the effects of different labor market institutions on inflation and output volatility. The eurozone offers an unprecedented experiment for this exercise: since 1999, no national monetary policies have been implemented that could account for volatility differences across member states, but labor market characteristics have remained very diverse. We use a New Keynesian model with unemployment to predict the effects of different labor market institutions on macroeconomic volatilities. In our subsequent empirical estimations, we find that higher labor turnover costs have a statistically significant negative effect on output volatility, while replacement rates have a positive effect, both of which are in line with theory. While labor market institutions have a large effect on output volatility, they do not seem to have much of an effect on inflation volatility, which can also be rationalized by our theoretical model.

JEL Classification: E24, E32, J20

Keywords: labor market institutions, output and inflation volatility, labor turnover costs, unemployment benefits, unemployment, eurozone

Corresponding author:

Christian Merkl

Kiel Institute for the World Economy

Duesternbrooker Weg 120

24105 Kiel

Germany

E-mail: christian.merkl@ifw-kiel.de

\footnotetext{
* We are grateful for comments from Eckhardt Bode, Ester Faia, Thomas Lubik, Paul Kramer, Johann Scharler, the participants of the seminars where the paper was presented and two anonymous referees. All remaining errors are our own.
} 


\section{Introduction}

What are the effects of different labor market institutions on the volatility of macroeconomic variables (macroeconomic volatilities henceforth), such as inflation and output? With risk averse agents and inflation costs, the answer to this question has important welfare and policy implications. It is highly relevant both for the (optimal) design of labor market institutions and for (optimal) fiscal and monetary policy. Further, it sheds light on the question which institutions should be integrated into labor market and business cycle models. There is a broad theoretical literature that touches this issue indirectly and a very recent empirical cross-country literature dealing with it more directly. ${ }^{1}$ However, so far there is no generally accepted view on the effect of labor market institutions on macroeconomic volatilities. We will argue below that the eurozone offers an unprecedented and so far largely unexplored experiment to analyze this question empirically.

The existing macro labor theory, which is centered around the search and matching model, indirectly touches the question how different labor market institutions affect macroeconomic volatilities. Hagedorn and Manovskii (2008) show that a high value of leisure (i.e., more generous unemployment benefits) increases the volatility of labor market variables in the search and matching model. Hall (2005) shows that real wage rigidities also have a positive effect on the volatility of labor market variables. ${ }^{2}$ These papers are very insightful from a theoretical point of view, but they cannot make any predictions on inflation volatility, as they assume perfectly flexible prices. Further, they do not tackle the empirical question whether labor market institutions actually affect macroeconomic volatilities, as predicted by the models.

There is a recent empirical cross-country literature (Abbritti and Weber (2008), Rumler and Scharler (2009)) that directly analyzes the effects of labor market institutions on macroeconomic volatilities. However, it suffers from two problems. (i) When two countries are hit by different macroeconomic shocks, macroeconomic volatilities would differ, even though they may have exactly the same labor market institutions. ${ }^{3}$ (ii) Even when two countries are hit by the same shocks and when they have the same labor market institutions, different monetary policy reactions may lead to completely different macroeconomic volatilities (see, e.g., Blanchard and Galí (2007), and an illustrative example later in this paper).

Our own paper is complementary to the above, while circumventing the two problems of cross-country studies, by making use of a natural experiment, the eurozone, whose members have substantially different labor market institutions. However, since 1999, the twelve founding states have been subject to the same monetary policy, and thus, differences in macroeconomic volatilities cannot be attributed to this factor. In addition, business cycles within the eurozone have shown a substantial synchronization. While there are countries like Ireland that have had a better growth performance, periods of high and low growth have been very similar in the entire eurozone. ${ }^{4}$ Therefore, after 10 years of existence, the eurozone provides an excellent

\footnotetext{
${ }^{1}$ Note that our paper focuses on business cycle volatility, while there is a broad literature on growth volatility (see, e.g., Klomp and de Haan, 2009, for a recent empirical contribution), which we will not touch.

${ }^{2}$ This literature was initiated by Costain and Reiter (2008) and Shimer (2005). All these papers discuss the ability of the search and matching model to replicate the volatility of labor market variables (e.g., unemployment, vacancies and the job finding rate). In contrast, we focus on output volatility for empirical reasons. The quality of output data in the eurozone is much better than the quality of employment data (due to structural breaks, comparability problems, etc.). It can, however, be shown in our model simulations that labor market institutions have the same qualitative effects on employment and output volatilities.

${ }^{3}$ Abbritti and Weber circumenvent this first problem in the most recent draft of their paper, by employing a panel Vectorautoregression approach.

${ }^{4}$ For instance, Benalal et al. (2006) write that while there remains some dispersion of real GDP growth rates, "the degree of synchronisation of business cycles across the euro area countries seems to have increased since the beginning of the 1990s, [and] the degree of correlation currently appears to be at an historic high" (p. 4).
} 
opportunity, largely unexplored so far, ${ }^{5}$ to learn more about the effects of different labor market institutions. We are well aware that the euro experiment also suffers from some shortcomings, such as the short observation period and the limited number of member states. However, we think that our approach generates interesting new insights that can be tested in a more detailed manner once more data becomes available on both the time dimension and the admission of more countries to the eurozone.

We proceed in two steps: First, we use a New Keynesian model that contains a new type of labor market model (see Lechthaler et al., 2010), which has so far not been used for this type of question, to analyze the effects of labor market institutions on macroeconomic volatilities, namely those of inflation and output. We use the second moments of the model economy to make theoretical predictions on the effects of firing costs (as they are known to be important in Europe $^{6}$ ) and unemployment benefit replacement rates (as they play an important role in the theoretical debate). Second, we run cross-country regressions on the effects of labor market institutions on macroeconomic volatilities.

Our analysis delivers the following results. As predicted by our model, there is a negative and significant correlation between labor turnover costs and output volatility, and there is a positive correlation between the replacement rate and output volatility. The picture looks different for inflation volatility, where labor market institutions in general do not have a great explaining power. We can rationalize this by our theoretical framework. Other than for output volatility, the effects of labor market institutions on inflation volatility depend on whether aggregate supply or demand shocks are at work. ${ }^{7}$ When both play an important role, the theoretical framework would not predict a clear-cut relationship between labor market institutions and inflation volatility.

The rest of the paper is structured as follows: Section 2 shortly describes the underlying labor market model, used to analyze macroeconomic volatilities. Section 3 presents the second moments, Section 4 presents the empirical strategy. Section 5 analyzes the connection between the theoretical and the empirical part and discusses open questions. Section 6 briefly concludes.

\section{The Model}

\subsection{Intuitive Description}

To illustrate the theoretical effects of labor market institutions on macroeconomic volatilities, we need to choose a model framework that is both suitable for business cycle analysis and rich enough to capture several labor market institutions. Therefore, we choose a standard New Keynesian sticky price model (to capture the business cycle dimension) which is enhanced by a labor market with match suitability shocks and labor turnover costs. The model details are laid out in Lechthaler et al. (2010) and Faia et al. (2009). ${ }^{8}$

\footnotetext{
${ }^{5}$ The only papers analyzing the impact of labor market institutions on macroeconomic fluctuations in a monetary union are Abbritti and Mueller (2007) and Campolmi and Faia (2010). However, the first paper does not contain an empirical part, and the second only focuses on the effects of replacement rates on inflation differentials.

${ }^{6}$ Blanchard and Wolfers (2000) show that the evolution of European unemployment can be explained by the interaction of shocks and labor market institutions. Among the latter, employment protection is significant in most of the cases. However, they only consider level effects and not the second moments. The role of labor turnover costs in macroeconomic models has recently been pointed out by Lechthaler et al. (2010) and Faia et al. (2009).

${ }^{7}$ We use shocks to the conduct of monetary policy (i.e., an aggregate demand shock) and productivity shocks (i.e., an aggregate supply shock). In contrast to inflation volatility, the effect of labor market institutions on output volatility does not depend on the type of shocks.

${ }^{8}$ For the model in partial equilibrium, see Snower and Merkl (2006).
} 


\section{Stylized Model Structure}

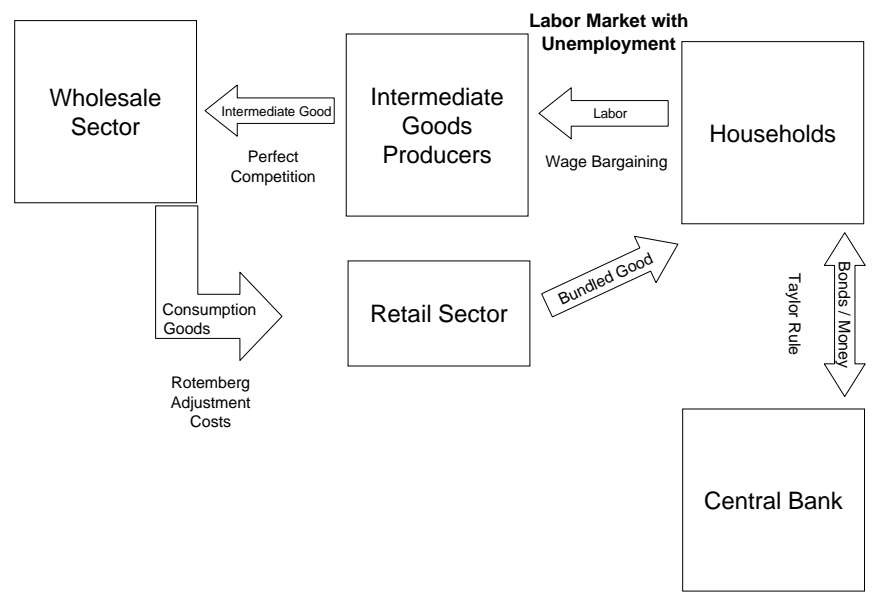

Figure 1: Model Structure

Figure 1 illustrates the structure of our model economy. As in the standard New Keynesian model, households maximize their intertemporal expected utility subject to their budget constraint. The wholesale sector acts under monopolistic competition and is subject to quadratic price adjustment costs à la Rotemberg. The monopolistic varieties are bundled by the retail sector. The central bank follows a Taylor rule. In contrast to the standard New Keynesian framework, we introduce an additional intermediate goods sector to model the labor market with unemployment. ${ }^{9}$

Firms and workers in our economy are subject to search frictions. Workers are able to contact one firm per period (which is one quarter in our discrete-time model) in order to find a suitable employer. Once workers have contacted a firm, their suitability is revealed (e.g., by performing an interview). We model the suitability by assuming an idiosyncratic operating cost shock, i.e., although all workers produce the same good, some are less suitable because they produce the good in more costly manner. Employers will only hire those workers with sufficiently low operating costs, up to a certain cut-off point. For simplicity, we assume that employed workers are subject to the same operating cost shocks as entrants. Further, we assume that the wage is bargained between the median incumbent worker (i.e., the worker who is in the middle of the idiosyncratic operating shock distribution) and the firm. ${ }^{10}$

Labor market institutions, namely labor turnover costs and unemployment benefits, are an explicit part of the model. We assume that unemployed worker obtain unemployment benefits (which allows us to calculate a replacement rate). Firms have to pay linear hiring and firing costs. These assumptions allow us to analyze the effects of labor market institutions on macroeconomic volatilities.

We deviate from the standard labor market approach, which assumes a time invariant matching function à la Pissarides (2000). Indeed, Shimer (2005) shows that the standard parametrization of a search and matching model is not able the replicate the fact that, for the United States, the standard deviation of labor market variables (e.g., the job-finding rate and the unemployment rate) is several times larger than the standard deviation of productivity (or

\footnotetext{
${ }^{9}$ The intermediate goods sector is introduced for analytical convenience. See Blanchard and Galí (2010) or Faia (2009) for other papers who also use an additional sector to integrate a search and matching model into a standard New Keynesian framework.

${ }^{10}$ The model mechanism would be similar under individualistic bargaining. However, our assumption that incumbent workers do the bargaining is particularly realistic for European economies.
} 
output). ${ }^{11}$ Further, when job destructions are endogenous (a hypothesis that is needed in order to analyze the role of firing costs), Krause and Lubik (2007) have pointed out that the search and matching model delivers several counterfactual correlations (e.g., a positive correlation between the job creation rate and the job destruction rate).

For analyzing the effect of labor market institutions on business cycle behavior, it is however crucial to use a framework that is in line with the stylized business cycle facts. Thus, our model assumes in contrast to the search and matching theory that the match suitability (i.e., the probability of finding a suitable employer, given a contact probability of one) and not the matching function determines the number of actual matches in the economy. ${ }^{12}$ This new modeling approach generates more realistic business cycle statistics, namely, a strong reaction of labor market variables to aggregate shocks and the right signs for the correlation between several variables (see Lechthaler et al., 2010, for details).

In sum, our theoretical approach has several advantages: (i) The use of a New Keynesian business cycle model with a recent new approach of modeling the labor market ensures that we can generate realistic labor market and business cycle statistics (see Lechthaler et al., 2010, for details). (ii) Our model contains several European type labor market institutions, which are the focus of the empirical analysis. (iii) Our labor market institutions are modeled explicitly and not as short-cut, as in some other papers. ${ }^{13}$

For brevity, we only show the labor market equations. All other parts correspond to an absolutely standard New Keynesian business cycle model. The entire set of equations can be found in the Technical Appendix.

\subsection{The Labor Market}

\subsubsection{Idiosyncratic Shocks and Labor Turnover Costs}

Intermediate goods firms (which sell their products to wholesale firms) hire labor to produce the intermediate good $Z$. Their production function is

$$
Z_{t}=A_{t} N_{t}
$$

where $A$ is the level of technology and $N$ is the number of employed workers. The parameter $A$ is subject to temporary technology shocks with an autoregressive component, $\rho_{a}$, and the standard deviation $\sigma^{\mu}$. Intermediate goods producers are price takers in a perfectly competitive environment, and sell their products at the relative price $M C_{t}=P_{z, t} / P_{t}$, where $P_{z}$ is the absolute price of the intermediate good and $P$ is the economy's overall price level. ${ }^{14}$

As described before, unemployed workers have to find a suitable employer. Once they are in contact with an employer, the match suitability is revealed. The match suitability is modeled as idiosyncratic operating cost shock, $\varepsilon_{t}$, at the beginning of the period, which can be interpreted as an idiosyncratic shock to workers' productivity or as a firm-specific idiosyncratic cost shock. The firms learn the value of the operating costs of every worker at the beginning of a period and base their employment decisions on this value, i.e., an unemployed worker associated with

\footnotetext{
${ }^{11}$ Gartner et al. (2009) show for Germany that the standard deviation of labor market variables is also several times larger than the standard deviation of productivity or output.

${ }^{12}$ In the search and matching model with endogenous separations, under certain timing assumptions the match suitability may also play a role for new matches. However, the way the model is conventionally parametrized, this role is minor.

${ }^{13}$ One example is Blanchard and Galí (2010) who model the more sclerotic European labor market vis-à-vis the U.S. labor market. For being able to obtain analytical solutions, they do not model any firing costs and heterogeneous match suitabilities. Instead, they generate sclerotic European labor markets, by assuming a smaller exogenous separation rate, a larger disutility of labor and a larger marginal hiring cost than in the United States.

${ }^{14} M C$ is the marginal cost for the wholesale sector.
} 
a sufficiently favorable shock will be employed, while an employed worker associated with a strong enough negative shock will be fired. ${ }^{15}$ However, hiring and firing is not costless. Firms have to pay linear hiring costs, $H$, and linear firing costs, $F$, both measured in terms of the final consumption good. These hiring and firing costs drive a wedge between the hiring decision and the firing decision. In their presence, the retention rate (i.e., 1 minus the firing rate) is always higher than the hiring rate (see Figure 2 in Lechthaler et al., 2010).

Indeed, each incumbent worker generates the following profit:

$$
\begin{aligned}
\tilde{\Pi}_{I, t}\left(\varepsilon_{t}\right) & =A_{t} M C_{t}-W_{t} / P_{t}-\varepsilon_{t} \\
& +E_{t} \sum_{i=t+1}^{\infty} \Delta_{t, i}\left[\begin{array}{c}
\left(1-\phi_{i}\right)^{i-t}\left(\begin{array}{c}
A_{i} M C_{i}-W_{i} / P_{i}- \\
E_{t}\left(\varepsilon_{i} \mid\left(1-\phi_{i}\right)\right)
\end{array}\right) \\
-\phi_{i} F\left(1-\phi_{i}\right)^{i-t-1}
\end{array}\right],
\end{aligned}
$$

where $\phi$ is the separation probability, $E_{t}\left(\varepsilon_{t+1} \mid\left(1-\phi_{t+1}\right)\right)$ the expected value of operating costs for an incumbent worker (i.e., conditional on retention), and $\Delta_{t, i}$ the stochastic discount factor from period $t$ to $i$ (i.e., the subjective discount factor $\beta$ weighted with the respective periods' marginal consumption utility). $W / P$ is the real wage, which is determined in a Nash bargain between firm and employed workers (see below).

Unemployed workers are hired whenever their operating cost does not exceed a certain threshold, such that the profitability of a worker is higher than the hiring cost, i.e., $\tilde{\Pi}_{I, t}\left(\varepsilon_{t}\right)>H$. Thus, the hiring threshold, $v_{h, t}$, (the value of the operating cost at which the firm is indifferent between hiring and not hiring an unemployed worker) is defined by

$$
\tilde{\Pi}_{I, t}\left(v_{h, t}\right)=A_{t} M C_{t}-W_{t} / P_{t}-v_{h, t}+E_{t}\left(\Delta_{t, t+1} \tilde{\Pi}_{I, t+1}\right)=H .
$$

Unemployed workers whose operating cost is lower than this value are hired, while those whose operating cost is higher are not. The resulting hiring probability is given by

$$
\eta_{t}=\Gamma\left(v_{h, t}\right)
$$

where $\Gamma$ is the cumulative density function of $\varepsilon$ from $-\infty$ to the cut-off point $v_{h, t}$.

The firm will fire a worker whenever $\tilde{\Pi}_{t}\left(\varepsilon_{t}\right)<-F$, i.e., when the operating costs are so high that it is more profitable for the firm to pay the cost of firing the worker. This defines the firing threshold, $v_{f, t}$ (the value of the operating cost at which the firm is indifferent between firing and retaining the worker), as

$$
\tilde{\Pi}_{I, t}\left(v_{f, t}\right)=A_{t} M C_{t}-W_{t} / P_{t}-v_{f, t}+E_{t}\left(\Delta_{t, t+1} \tilde{\Pi}_{I, t+1}\right)=-F .
$$

Thus, the separation rate is

$$
\phi_{t}=1-\Gamma\left(v_{f, t}\right) .
$$

We thus obtain the usual employment dynamics curve

$$
n_{t}=n_{t-1}\left(1-\phi_{t}-\eta_{t}\right)+\eta_{t},
$$

where $n$ is the employment rate.

\footnotetext{
${ }^{15}$ For simplicity, we assume that there are identical operating cost shocks for entrants and incumbent workers. Note, however, that it would also be possible to have constant productivity for incumbent workers (see, e.g., Gartner et al., 2009). But as we want to analyze the effects of firing costs, we need to model job destruction endogenously.
} 


\subsubsection{Wage Bargaining}

The real wage is the outcome of a Nash bargain between the median incumbent worker and her firm, and is renegotiated in each period $t .{ }^{16}$ When both parties agree, the worker receives the real wage $W_{t} / P_{t}$ and the firm receives the expected profit $A_{t} M C_{t}-W_{t} / P_{t}-\varepsilon^{I}$ in each period $t$. When they disagree, the worker's fallback income is $B_{t}$, assumed for simplicity to be equal to the real unemployment benefit. The firm's fallback profit assumed to be equal to $-S$, which is the cost of not producing. ${ }^{17}$ Consequently, the Nash-product is

$$
\Lambda=\left(W_{t} / P_{t}-B_{t}\right)^{\gamma}\left(A_{t} P_{z, t}+S-W_{t} / P_{t}-\varepsilon^{I}\right)^{1-\gamma},
$$

where $\gamma$ represents the bargaining strength of the incumbent worker relative to the firm. Maximizing the Nash product with respect to the real wage, yields the following equation:

$$
W_{t} / P_{t}=\gamma\left(A_{t} M C_{t}+S-\varepsilon_{t}^{I}\right)+(1-\gamma) B
$$

Further details on the wage bargaining and the rest of the model can be found in Lechthaler et al. (2010) and Faia et al. (2009).

\subsection{Frictional Labor Market and Marginal Costs}

It is well-known that the loglinearized Phillips Curve in the standard New Keynesian model looks as follows:

$$
\hat{\pi}_{t}=\beta E_{t} \hat{\pi}_{t+1}+\frac{\varepsilon-1}{\Psi} \hat{m} c_{t}
$$

where $\pi$ is the inflation rate, $m c$ are the marginal costs, $\varepsilon$ is the elasticity of substitution between different goods types (in the monopolistically competitive sector) and $\Psi$ is the Rotemberg adjustment cost parameter. In a model with frictionless labor market and constant returns to scale, the marginal costs are equal to the wage divided by productivity.

In our model, marginal costs are determined by the wage (as in the standard model), the hiring threshold, $v_{h, t}$, the hiring costs, $H$, and the expected future profits, $E_{t}\left(\Delta_{t, t+1} \tilde{\Pi}_{I, t+1}\left(\varepsilon_{t+1}\right)\right)$.

$$
M C_{t}=\frac{W_{t}}{A_{t}}+\frac{v_{h, t}}{A_{t}}+\frac{H}{A_{t}}-\frac{E_{t}\left(\Delta_{t, t+1} \tilde{\Pi}_{I, t+1}\left(\varepsilon_{t+1}\right)\right)}{A_{t}}
$$

In this context, marginal costs depend on two additional components (besides wages), namely the marginal workers' hiring threshold, $v_{h, t}$, and the expected future profits of an average worker, $E_{t}\left(\Delta_{t, t+1} \tilde{\Pi}_{I, t+1}\left(\varepsilon_{t+1}\right)\right)$. These two components vary endogenously and drive a wedge between marginal costs in a frictionless economy and an economy with labor turnover costs.

As a consequence, each macroeconomic shock (e.g., a productivity shock) is associated with an endogenous cost-push shock, as it varies the hiring and firing thresholds. Put differently, whenever an aggregate shock leads to an expansion of the economy, the cost of production increases for intermediate goods producers, as they will also have to hire (or retain) workers that are less suitable (i.e., the hiring threshold, $v_{h, t}$, will increase endogenously). This issue will become important when we discuss the effects of labor market institutions on inflation volatility and the associated role of aggregate demand and supply shocks.

Faia et al. (2009) show that these wedges are very important for optimal monetary policy. While in the standard model, it is always optimal to stabilize inflation to zero when the economy is hit by productivity shocks, this is no longer the case in the framework with labor turnover

\footnotetext{
${ }^{16}$ See, e.g., Grüner (2010) for a bargaining mechanism in similar spirit.

${ }^{17}$ There may be a fixed cost of production or workers may impose a cost on the firm in case of disagreement.
} 
costs. Optimal inflation volatility is a positive function of labor turnover costs (i.e., monetary policy should allow for higher inflation volatility, the higher the labor turnover costs are). When employment adjustment becomes more costly, the social planner will face inflation costs and employment adjustment costs. With a more sclerotic labor market, the social planner will be willing to accept somewhat higher inflation costs in order to reduce the employment adjustment costs.

\subsection{Monetary Policy}

We assume that monetary policy follows a standard Taylor rule:

$$
\left(\frac{1+i_{t}}{1+\bar{\imath}}\right)=\left(\frac{\pi_{t}}{\bar{\pi}}\right)^{\alpha_{\pi}} e^{\omega_{t}}
$$

where $\pi_{t}$ is the gross inflation rate, $\bar{\pi}$ is the central bank inflation target, $\bar{\imath}$ is the steady state interest rate and $\omega_{t}$ is an uncorrelated shock term (i.e., there is either an unsystematic deviation of the central bank from its rule or the central bank cannot control the relevant interest rate perfectly), with standard deviation $\sigma^{\omega}$.

\subsection{Parametrization}

The Rotemberg adjustment costs are set in line with microevidence. ${ }^{18}$ The elasticity of substitution, $\varepsilon$, in the monopolistic sector is set to 10 .

In our standard parametrization, we set the values for labor market institutions to represent a typical eurozone country. Bargaining power, $\zeta$, is set to 0.5 and unemployment benefits, $b$, are set to $64 \%$ of a worker's average productivity (her annual productivity, $A$, is normalized to 1), i.e., to roughly $70 \%$ of the wages. Linear hiring costs are $10 \%$ and linear firing costs are $60 \%$ of annual productivity (see Bentolila and Bertola, 1990, Chen and Funke, 2005). The model is parametrized to represent the labor market flow rates of a typical continental European economy $(\phi=0.02, \eta=0.2) \cdot{ }^{19}$ A summary of all parametrization values can be found in Table 1.

Table 1: Parametrization

\begin{tabular}{||c||c||c||c||c||c||c||c||}
\hline \hline$\beta$ & 0.99 & $S$ & 0.2879 & $A$ & 1 & $\alpha_{\pi}$ & 1.5 \\
\hline \hline$\sigma$ & 2 & $F$ & 0.6 & $\rho_{a}$ & 0.95 & $E(\varepsilon)$ & 0 \\
\hline \hline$\varepsilon$ & 10 & $H$ & 0.1 & $\sigma^{\mu}$ & 0.005 & $s d$ & 0.53 \\
\hline \hline$\Psi$ & 104.85 & $b$ & 0.64 & $\sigma^{\omega}$ & 0.0015 & $\zeta$ & 0.5 \\
\hline \hline
\end{tabular}

\section{Macroeconomic Volatilities: Theory}

We use our benchmark parametrization and conduct ceteris paribus analyses for two labor market institutions (firing costs and unemployment replacement rates) and different conducts

\footnotetext{
${ }^{18}$ The reduced form parameter in the New Keynesian Phillips curve is the same as with Calvo price staggering and an average price duration of four quarters.

${ }^{19} \mathrm{~A}$ logistic distribution is chosen for the idiosyncratic operating cost shock. The mean, $E(\varepsilon)$, is normalized to zero. The dispersion of the distribution, $s d$, and the fall-back option of the firm under disagreement, $-S$, are chosen to obtain the desired flow rates (see Wilke (2005) for the labor market flow rates).
} 
of monetary policy. This means that we just vary one parameter, keeping all others constant, and that we analyze how this changes the impulse response functions and the Hodrick-Prescott (HP) filtered volatilities of output and inflation (to make the theoretical exercise comparable to the empirical exercise, we use a smoothing parameter $\lambda=1,600) .{ }^{20}$ For illustration purposes, we show the impulse response functions (IRFs) in reaction to a one standard deviation shock to productivity, with an autocorrelation of 0.95 and a standard error of 0.005 . When we calculate business cycle statistics (i.e., standard deviation of inflation and output), we assume that the economy is also subject to aggregate demand shocks, namely, interest rate shocks. As usual in the literature, we model interest rate shocks to be uncorrelated. We assume a standard error of $0.0015 .^{21}$

\subsection{Different Firing Costs}

In addition to our standard parametrization, we also set firing costs (FC) to 0.5, 0.7 and 0.8, keeping all other parameters values constant. Visual inspection of the IRFs (see Figure 2) shows that higher firing costs clearly reduce the volatility of output after a productivity shock. The mechanism involved is straightforward. Higher firing costs reduce labor market flows (both hiring and firing). Therefore, an economy with higher firing costs reacts in a more sclerotic manner: both the initial job creation in reaction to a positive shock and the rate at which the output path declines as the shock fades slow down. The view that higher firing costs dampen output volatility (for a given set of shocks) is confirmed by the business cycle statistics (see Table 2).
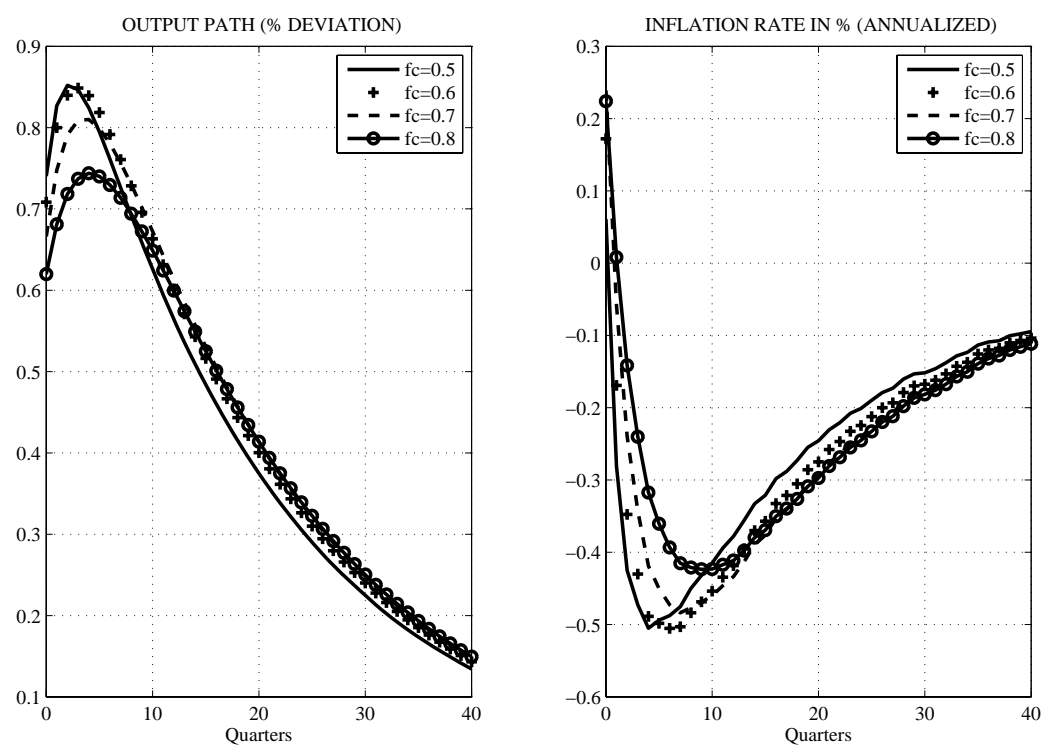

Figure 2: Impulse Response Functions to a One Standard Deviation Productivity Shock for Different Firing Costs $(f c=0.5,0.6,0.7,0.8)$.

While the IRFs for the inflation rate also point into the direction that higher firing costs increase volatilities, this view is not necessarily confirmed by the business cycle table, where the picture

\footnotetext{
${ }^{20}$ All our graphs are based on a second order approximation. In the business cycel statistics, we divide the standard deviation by the mean of the respective variable.

${ }^{21}$ The numbers for the standard error of the productivity shock and the interest rate shock are broadly in line with de la Croix et al., 2007, and Smets and Wouters, 2003, 2005.
} 
is less clear. The type of shock matters for inflation volatility. This is illustrated by the last two lines in Table $2 .^{22}$

Table 2: Volatilities for Different Firing Costs

\begin{tabular}{ll|c|c|c|c} 
& Volatilities & $\mathbf{F C}=\mathbf{0 . 5}$ & $\mathbf{F C}=\mathbf{0 . 6}$ & $\mathbf{F C}=\mathbf{0 . 7}$ & $\mathbf{F C}=\mathbf{0 . 8}$ \\
\hline Joint Shocks & $\pi$ & 0.17 & 0.18 & 0.14 & 0.12 \\
\hline & $\mathbf{Y}$ & 1.17 & 1.14 & 1.07 & 0.97 \\
\hline Productivity Shocks & $\pi$ & 0.16 & 0.16 & 0.15 & 0.12 \\
\hline & $Y$ & 1.17 & 1.14 & 1.07 & 0.97 \\
\hline Interest Rate Shocks & $\pi$ & 0.067 & 0.067 & 0.069 & 0.073 \\
\hline & $Y$ & 0.030 & 0.025 & 0.021 & 0.017 \\
\hline
\end{tabular}

The results for inflation volatility can be explained as follows. Inflation is a function of the current and all expected future marginal costs (see equation 10, where the expected inflation term can be substituted out). When a productivity shock hits the economy, this reduces marginal costs (as each worker can produce more output). As a consequence, firms will hire (retain) workers that are less suitable (i.e., the marginal worker has higher operating costs). Thereby, the economy is hit by an endogenous cost-push shock, increasing marginal costs (see equation 11)

Higher firing costs lead to a more severe immediate endogenous cost-push shock. This can clearly be seen in Figure 2, where the initial inflation reaction even becomes positive when the firing costs are sufficiently large.

Thus, a positive productivity shock reduces marginal costs, while the endogenous cost-push shock increases them. Under low firing costs, the endogenous cost-push shock is moderate and the effects of the productivity shock are dominant. As a consequence, with low firing costs the wholesale goods producing sector is able to reduce prices substantially when the shock hits. However, once the shock starts disappearing, it will increase prices by more. As a consequence, lower firing costs may lead to larger price fluctuations (i.e., more inflation volatility) under productivity shocks.

Under interest rate shocks, the aggregate productivity remains constant. The output expansion will be associated with an endogenous cost-push shock. The more costly the employment adjustment (i.e., the higher the firing costs), the more severe will be the cost-push shock. As a consequence, higher firing costs lead to a faster price adjustment and thereby more inflation volatility.

We can sum up that our model predicts that higher firing costs lead to less output volatility, irrespective of the shock considered. In contrast, the model cannot make any clear-cut predictions for the effects of firing costs on inflation volatility. The effects depend on the relative magnitude of aggregate demand vis-à-vis aggregate supply shocks.

\subsection{Different Replacement Rates}

In addition to our standard parametrization, we also set the steady state unemployment replacement rate $(\mathrm{RR})$ to $0.65,0.675$ and 0.725 , keeping all other parameters values constant. As shown in Figure 3, the impulse response functions indicate that higher unemployment benefit replacement rates (measured as the unemployment benefits divided by the wage in the steady state) increase the output volatility. This can also be clearly seen in Table 3.

\footnotetext{
${ }^{22}$ Obviously, under our chosen calibration (which is in line with estimated dynamic stochastic general equilibrium models), the productivity shock is dominant in driving aggregate fluctuations. If we gave a more important weight to the interest rate shock, inflation volatility may depend positively on firing costs.
} 
In our model, higher unemployment benefits increase workers' fallback position. This has two effects: (i) The wage in the economy increases. Thus, higher unemployment benefits increase job destruction and reduce job creation, thereby pulling in different directions (the former makes the labor market more fluid, while the latter has the opposite effect). (ii) When the net replacement rate $(B / W)^{23}$ increases, a larger share of the wage is fix (see equation 9 ). This reduces the relative fluctuations of the wage (for a given variation of the marginal costs, $M C)$. Thus, we expect that the reduced wage fluctuations increase the output fluctuation. And this view is confirmed by the second moments in Table 3.
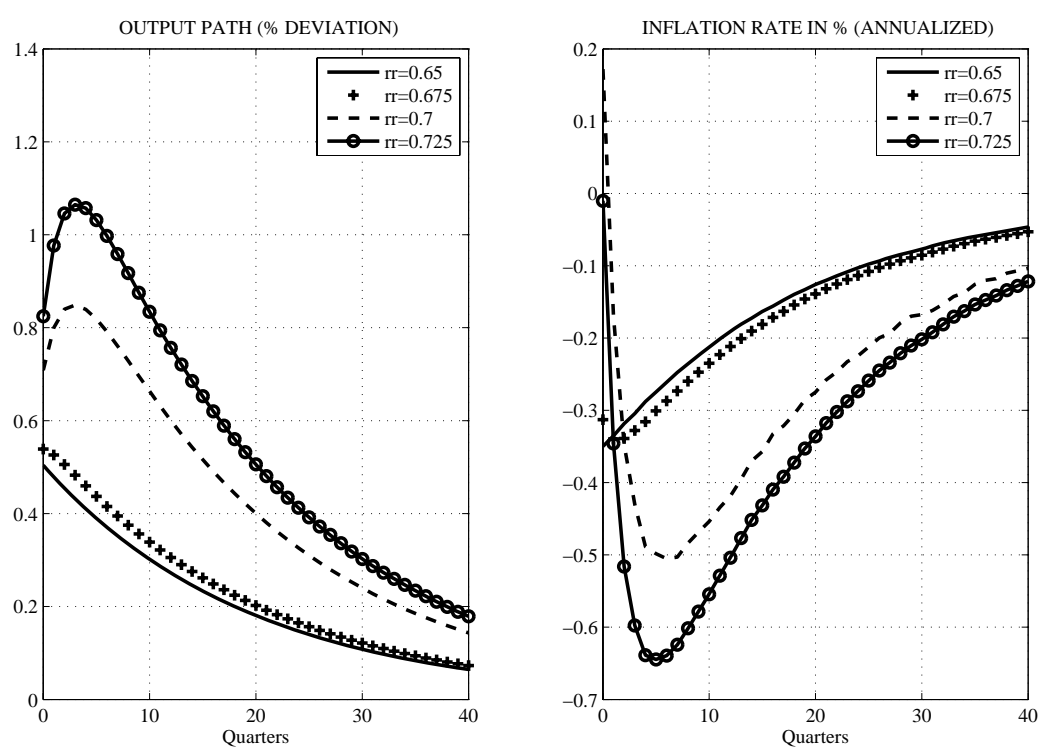

Figure 3: Impulse Response Functions to a One Standard Deviation Shock for Different Replacment Rates $(R R=0.65,0.675,0.7,0.725)$.

Similar to firing costs, the effect of unemployment benefits on inflation volatility depends on the type of shock (see Table 3). Higher unemployment benefits may imply higher inflation volatility under aggregate supply shocks (i.e., productivity shocks in our case), while they imply lower inflation volatility under aggregate demand shocks (i.e., interest rate shocks in our case).

The intuition is the same as for different firing costs. Under aggregate productivity shocks and low replacement rates, the reduction of marginal costs (due to productivity shocks) and the increase of marginal costs (due to the endogenous cost-push shock) move into opposite directions. However, under interest rate shocks, there is no countervailing effect that reduces marginal costs. Thus, if aggregate demand shocks are dominant in the economy, higher unemployment benefits imply lower inflation volatility. If aggregate supply shocks are dominant, the opposite may be the case. Thus, our model cannot make any clear-cut predictions for the effects of replacement rates on inflation volatility.

\footnotetext{
${ }^{23} \mathrm{P}$ is equal to 1 in the steady state.
} 
Table 3: Volatilities for Different Unemployment Benefits

\begin{tabular}{ll|c|c|c|c} 
& Volatilities & $\mathbf{R R}=\mathbf{0 . 6 5}$ & $\mathbf{R R = 0 . 6 7 5}$ & $\mathbf{R R}=\mathbf{0 . 7}$ & $\mathbf{R R}=\mathbf{0 . 7 2 5}$ \\
\hline Both Shocks & $\pi$ & 0.15 & 0.15 & 0.18 & 0.20 \\
\hline & $\mathbf{Y}$ & 0.65 & 0.72 & 1.15 & 1.41 \\
\hline Productivity Shocks & $\pi$ & 0.12 & 0.11 & 0.16 & 0.20 \\
\hline \multicolumn{2}{c|}{$\mathbf{Y}$} & 0.65 & 0.72 & 1.14 & 1.41 \\
\hline Interest Rate Shocks & $\pi$ & 0.10 & 0.09 & 0.07 & 0.05 \\
\hline \multicolumn{2}{r|}{$\mathbf{Y}$} & 0.000 & 0.005 & 0.025 & 0.029 \\
\hline
\end{tabular}

\subsection{Different Monetary Policy Rules}

Table 4 shows the volatility of model economies with the same aggregate shocks (productivity and interest rate shocks) and the same labor market institutions, but different weights on inflation in the Taylor rule. It can be seen that different monetary policy rules change volatilities substantially, potentially reversing the impact of different labor market institutions. Therefore, we consider the eurozone to be particularly suitable for a case study, as all its members are subject to the same monetary policy.

Table 4: Volatilities for Different Weights in the Taylor Rule

\begin{tabular}{cl|c|c|c} 
& Volatilities & $\alpha_{\pi}=\mathbf{1 . 0 1}$ & $\alpha_{\pi}=\mathbf{1 . 5}$ & $\alpha_{\pi}=\mathbf{2}$ \\
\hline Both Shocks & $\pi$ & 0.98 & 0.18 & 0.13 \\
\hline \multirow{2}{*}{$\mathbf{Y}$} & 0.60 & 1.14 & 1.18
\end{tabular}

\subsection{Summary of the Theoretical Predictions}

Our employed theoretical framework predicts a negative correlation between the magnitude of firing costs and output volatility in an economy. Further, it predicts a positive correlation between the replacement rate and output volatility. The predictions for the connection between the two labor market institutions and inflation volatility are less clear, as they depend on whether aggregate demand or supply shocks are the dominant source of aggregate fluctuations in an economy. If the economy is mainly driven by aggregate supply shocks, the predicted correlations are the same as for output volatility, while they are the opposite if aggregate demand shocks are dominant.

Since we are interested in the effects of labor market institutions, we employed a theoretical business cycle framework with frictional unemployment. Under this framework, a different conduct of monetary policy (e.g., different reactions to inflation) leads to radically different inflation and output volatilities. Therefore, the European Monetary Union (EMU) is the natural choice for our empirical part. The EMU contains a set of countries with substantially heterogeneity in the design of the labor market institutions. Further, all these countries are subject to the same monetary policy, thereby preventing distortions from this source, and they faced a fairly synchronized business cycle during our chosen observation period. 


\section{Macroeconomic Volatilities: Empirics}

\subsection{Indicators and Data Sources}

\subsubsection{Macroeconomic variables}

Our empirical analysis of the eurozone covers 11 countries $^{24}$ and a time span of nearly ten years, from the first quarter of 1999 to the second quarter of 2008. Just like in the simulations above, we focus on the movements of output and inflation ${ }^{25}$, on a quarterly basis.

Output is measured using real GDP, taken from the IFS (Issue 10/2008), and inflation is measured using the GDP deflator ${ }^{26}$ from the same database. All time series are seasonally adjusted. To assess the cyclical behavior of output, we consider the output gap, i.e., the percentage deviation of the time series from its trend, calculated using an HP filter (with $\lambda=1,600$ ). For inflation, we simply consider the cyclical component of the series (the difference between the series and its trend, computed using the same filter). ${ }^{27}$ Volatility is defined as the standard deviation of these two cyclical measures.

\subsubsection{Labor Market Institutions}

We use the OECD's (2004) employment protection legislation measure (EPL) to model labor turnover costs (LTC). This index is calculated as a weighted average of measures for the protection of regular workers against individual dismissals, requirements for collective dismissals, and regulation of temporary employment. ${ }^{28}$ Compared with other measures, such as the employment legislation index created by Botero et al. (2004), or the hiring and firing costs calculated in the World Bank's "Doing Business" studies (2008), the EPL both covers a larger range of relevant aspects of LTC and is computed in a more precise and differentiated way. The OECD published EPL figures only once in our observation period, for the year 2003.

A first graphical inspection of the EPL measure plotted against the volatility of the output gap (VOG), as shown in Figure 4, reveals a negative correlation, significant at a $5 \%$ level. Moreover, the relationship appears to be fitted best by a hyperbola, so that there may be some evidence for it being nonlinear.

The generosity of unemployment benefits can be measured by replacement rates, which are also established by the OECD (2007). It defines the net replacement rate (NRR) as the ratio between net income while out of work and net income while in work. By taking a simple average of the NRR over 60 months of unemployment, for four different family types, and two different income levels, a "synthetic overall measure of the generosity of benefits relative to net earnings" (OECD (2007), p. 99) is obtained. This measure is calculated in two specifications (with and without taking into account social assistance) and has been published yearly since 2001 . Previously, the OECD had also established a gross replacement rate (GRR), covering a much longer time period (1961-2005). Computed similarly to the NRR, it neglected nevertheless a certain number of elements, such as taxes or family-related benefits, and should therefore be less precise. For our analysis, we thus retain the NRR (including social assistance), but we

\footnotetext{
${ }^{24}$ The 12 founding members, excluding Luxembourg, due to a lack of labor market indicators.

${ }^{25}$ Employment fluctuations have also been considered. However, the data is less reliable due to more structural breaks and changes in the unemployment definitions.

${ }^{26}$ The GDP deflator is more in line with the theoretical framework than the CPI, because the former only includes domestically produced goods, i.e., goods that are subject to domestic price rigidities.

${ }^{27}$ The inflation gap may be indefinite if the trend is equal to zero. Therefore, we do not choose percentage deviations. However, our theoretical predictions would be unaffected by this transformation.

${ }^{28}$ The inclusion of the regulation of temporary employment is important. First, it was in the focus of labor market reforms during our observation period. Second, large hiring and firing costs for regular workers may cause firms to use temporary work agencies (see, e.g., Chen and Funke, 2009).
} 


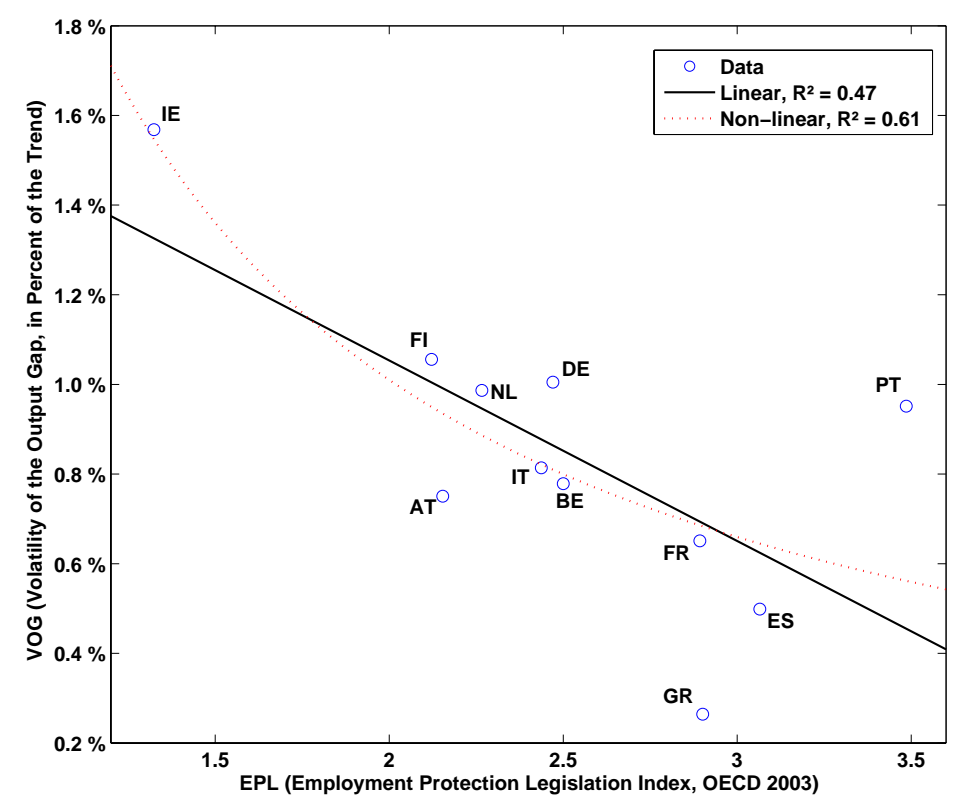

Figure 4: EPL and the Volatility of the Output Gap

also consider the GRR, for comparison and robustness purposes. As for the EPL, we use the values in 2003 for the NRR. For the GRR, we use the simple average of its values in the period $1999-2005 .{ }^{29}$

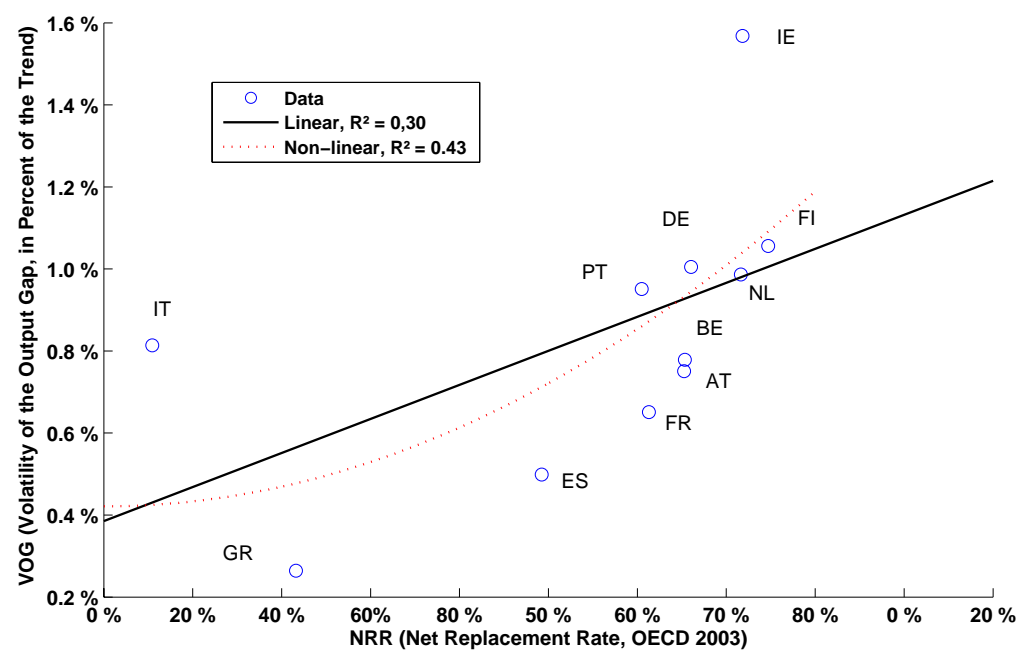

Figure 5: NRR and the Volatility of the Output Gap

When we plot the NRR against the volatility of the output gap (see Figure 5), there is a positive correlation, although it is weaker than the one found for the EPL, being significant only at a $10 \%$ level. Again, there may be some evidence for a nonlinear relationship.

Finally, when we plot the EPL against the inflation volatility (see Figure 6), there is a

\footnotetext{
${ }^{29}$ Using the GRR's value in 2003 does not affect the results. In fact, with the exception of the Netherlands, countries' GRR is almost stable during the period under consideration.
} 


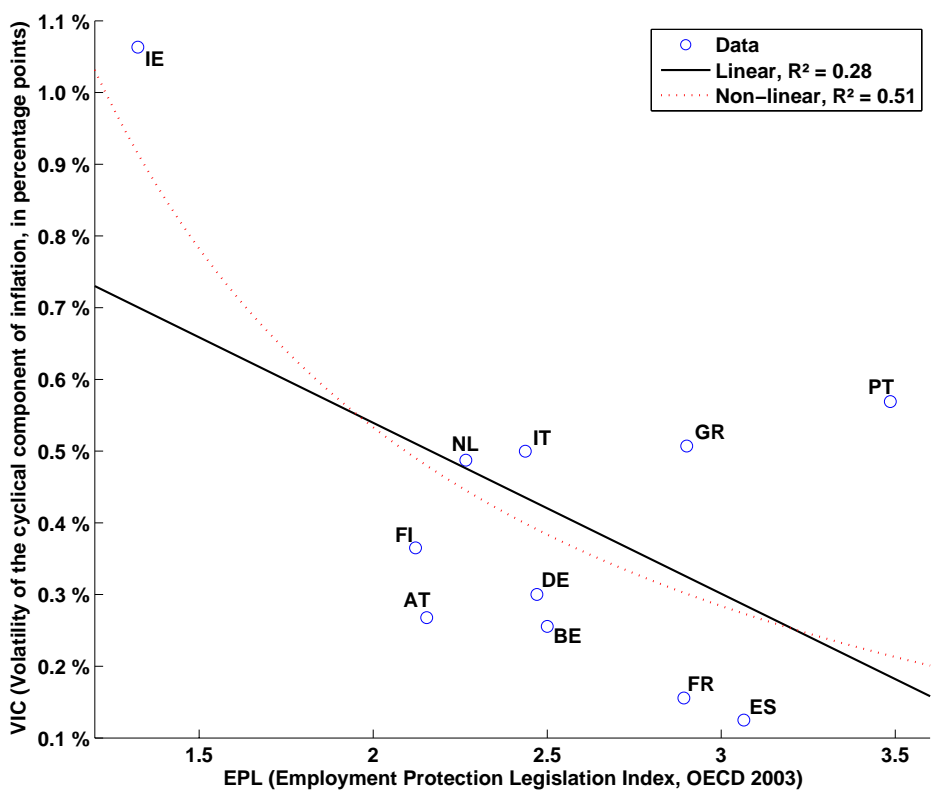

\section{Figure 6: EPL and the Volatility of the Cyclical Component of Inflation}

weak negative correlation. There is virtually no correlation between the NRR and the inflation volatility (see Figure 7).

\subsubsection{Control variables}

As labor market institutions are of course not the only possible source of differences in macroeconomic volatilities, we choose a set of control variables. Following the choices made by Rumler and Scharler (2009), we choose the average real GDP per capita (GDPPC), the volatility of government expenditure (VGE), the volatility of terms of trade, the volatility of import prices, union density and the coordination of the wage-setting process. Additionally, we also take into account the average quarterly growth rate (GROWTH), the average real GDP (to control for size effects), and the average quarterly inflation rate. Table 6 shows the coefficients of correlation between these control variables with either the volatility of inflation or output (if they are at least significant at the 10 percent level). ${ }^{30}$

\section{Table 5: Control Variables}

\begin{tabular}{|l|l|l|}
\hline Coefficient of Correlation & VOG & VIC \\
\hline GDPPC & $0.54^{*}$ & - \\
\hline GROWTH & - & $0.55^{*}$ \\
\hline VGE & - & $0.77^{* * *}$ \\
\hline
\end{tabular}

Explanations: $* * *$ significant at $1 \%, * *$ significant at $5 \%, *$ significant at $10 \%$.

\footnotetext{
${ }^{30}$ We also experimented with different control variables for the country specific financial system (such as the private credit by deposit money banks/GDP, bank deposits/GDP, bank concentration, stock market total value traded/GDP, a dummy variable bank or market oriented banking system). However, they all showed no significant correlation with output and inflation volatility. Thus, we do not show them in our analysis. Further, we experimented with loan-to-value ratios, as proposed by Bertola and Koeniger (2007). They also showed no significant relations with output and inflation volatility. Results are available on request.
} 


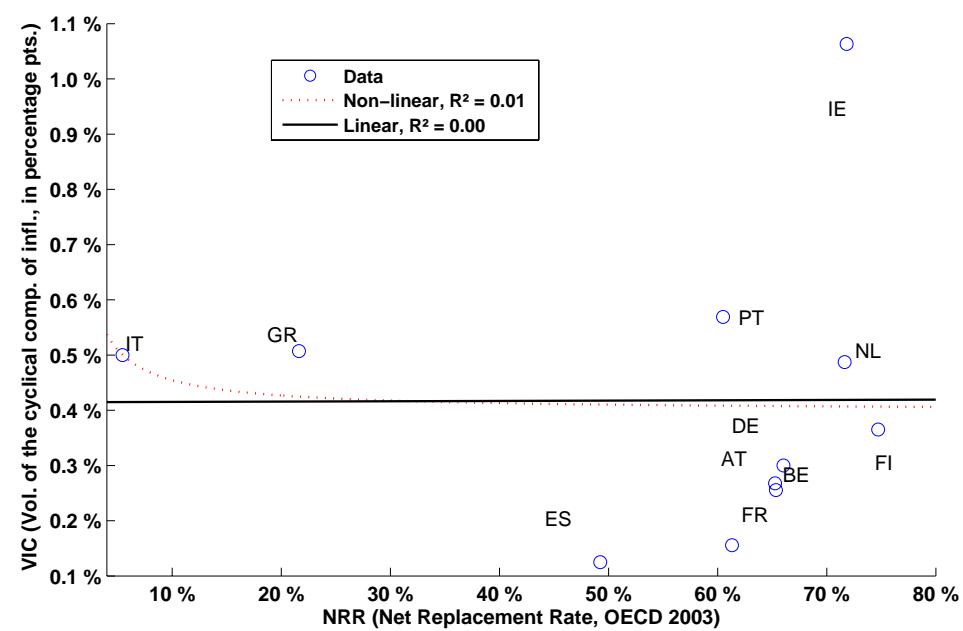

Figure 7: NRR and the Volatility of the Cyclical Component of Inflation

Data sources and details on the computation of the control variables, as well as more precise information on all macroeconomic and labor market variables can be found in the Appendix.

\subsection{Estimations}

\subsubsection{Output Gap Volatility}

In this section, we look at a simple regression model, considering the joint impact of labor turnover costs, replacement rates, a possible interaction between the two, and control variables on the volatility of the output gap. This model has thus the form:

$$
V O G_{i}=\beta_{0}+\beta_{1} L T C_{i}+\beta_{2} R R_{i}+\beta_{3}\left(L T C_{i} * R R_{i}\right)+\beta_{4} \text { Control }_{i}+\varepsilon_{i}
$$

As we have two different measures for replacement rates (NRR and GRR), this gives us two different models to estimate. The limited amount of observations does not allow a large number of control variables. As indicated by Table 6, the only control variable that is significantly correlated with VOG is GDP per capita (GDPPC). Thus, we use this variable in our estimations.

The model is estimated with an OLS step-down regression procedure, eliminating at each step the least significant variable, until only variables with a significance level below $5 \%$ are left. In all results shown below, the specification of the reduced model could not be rejected at a $5 \%$ level, using a general F-test, showing that the dropped variables can indeed be omitted. 
Table 6: Output Volatility: Linear Results

\begin{tabular}{|l|l|c|c|}
\hline & & Model 1 & Model 2 \\
\hline & Constant & $10.761^{* * *}$ & $5.941^{* * *}$ \\
\hline LTC & EPL & $-2.928^{* *}$ & $-1.391^{* * *}$ \\
\hline RR & NRR & $-6.540^{* *}$ & \\
\hline & GRR & & (dropped) \\
\hline Interaction & EPL*NRR & $2.935^{* *}$ & \\
\hline & EPL*GRR & & $0.9436^{* * *}$ \\
\hline Control & GDPPC & $-0.112^{* *}$ & $-0.093^{* *}$ \\
\hline & $\mathrm{R}^{2}$ & 0.87 & 0.85 \\
\hline & $\mathrm{R}^{2}($ adj $)$ & 0.78 & 0.79 \\
\hline & F-Stat. & $9.70^{* * *}$ & $13.30^{* * *}$ \\
\hline
\end{tabular}

Explanations: $* * *$ significant at $1 \%, * *$ significant at $5 \%, *$ significant at $10 \%$.

The results, shown in Table 7, indicate a high overall fit for the two models. The interaction terms are found to be significant, indicating that the impacts of labor market institutions are not independent from one another.

EPL is significant in both specifications, and as hinted by our initial graphical analysis, it is negatively correlated with VOG (as NRR and GRR are both always between 0 and 1). Moreover, an increase of EPL by one standard deviation (0.575) would lower output volatility by between 0.42 and 1.60 percentage points in the first, and 0.54 and 0.72 in the second model, showing that the variable is not only statistically, but also economically relevant. ${ }^{31}$

Replacement rates, which are less correlated with VOG, are also found to be significant. As predicted by theory, higher replacement rates are generally correlated with higher output volatility. This is always the case in the model using the GRR measure, where an increase of one standard deviation (0.089) increases output volatility by between 0.11 and 0.29 percentage points. When using the NRR, the impact of the replacement rate depends on the level of labor turnover costs: it is positive in the case where EPL is larger than 2.23 (which is the case for 8 out of the 11 countries of our sample), and negative elsewhere. In sum, its impact (after an increase by one standard deviation $(0.223)$ ) ranges between a 0.59 percentage point decrease and a 0.82 point increase of output volatility.

Thus, while the impact of labor turnover costs appears unambiguous, that of replacement rates, though generally positive, is less important and depends in a stronger way on interaction effects.

Finally, the control variable GDP per capita is significant. Higher GDP per capita seems to be correlated with lower output volatility, a result that is in line with other studies, such as Beck et al. (2006).

However, even though those models are significant, graphical analysis suggested that a linear relationship between the explaining variables and VOG may not always be the most appropriate specification. Therefore, we estimated the two models above again, using nonlinear transformations of the explanatory variables (either hyperbolic, i.e., using $1 / X$ instead of $X$ as explanatory variable, or quadratic, i.e., using $\left.X^{2}\right) .{ }^{32}$ Results are shown in Table 8. To a large extent, they confirm those of the linear models, indicating their robustness.

\footnotetext{
${ }^{31}$ The standard deviation of the explained variable VOG is 0.33 .

${ }^{32}$ The variable chosen was the one found to be most significant in an individual regression, using $\mathrm{X}$ as the only explanatory variable. There was always at least one of the two non-linear specifications that gave better results than the linear one.
} 
Table 7: Output Volatility: Nonlinear Results

\begin{tabular}{|l|l|c|c|}
\hline & & Model 1 & Model 2 \\
\hline & Constant & $-3.795^{* *}$ & 0.316 \\
\hline LTC & $1 / \mathrm{EPL}$ & $13.875^{* * *}$ & $2.025^{* * *}$ \\
\hline RR & NRR 2 & $9.470^{* * *}$ & \\
\hline & $1 / \mathrm{GRR}^{* *}$ & & $-0.101^{* *}$ \\
\hline Interaction & $1 / \mathrm{EPL}^{*} \mathrm{NRR}^{\wedge} 2$ & $-21.262^{* *}$ & \\
\hline & $1 / \mathrm{EPL}^{*} 1 / \mathrm{GRR}^{*}$ & & (dropped) \\
\hline Control & $\mathrm{GDPPC}^{\wedge} 2$ & $-0.00002^{* * *}$ & (dropped) \\
\hline & $\mathrm{R}^{2}$ & 0.93 & 0.78 \\
\hline & $\mathrm{R}^{2}($ adj $)$ & 0.88 & 0.72 \\
\hline & $\mathrm{F}-S t a t .^{2}$ & $18.68^{* * *}$ & $13.79^{* * *}$ \\
\hline
\end{tabular}

Explanations: $* * *$ significant at $1 \%,{ }^{* *}$ significant at $5 \%, *$ significant at $10 \%$.

EPL is again significant in both models, as a volatility-reducing factor. Its economic impact is smaller than in the linear models (raising EPL by one standard deviation, starting from its mean value, lowers the volatility by between 0.11 and 0.75 percentage points in the first model, and by 0.11 in the second one). The results for replacement rates are somewhat weaker, as their impact is always positive only in the case where the GRR is used (in this case, the impact of an increase of one standard deviation, starting from the mean GRR, increases output volatility by 0.06 percentage points). When the NRR is used, the impact is positive only when the threshold of an EPL of 2.24 is passed (which is again the case for 8 of the 11 countries of our sample).

When considering these results, one should obviously have in mind that the available dataset is limited, both regarding the number of countries included and the number of years considered for the volatility calculations. Therefore, our results should be seen as giving a first insight of the relative importance of the different variables, rather than a definitive conclusion. This first insight we obtain from our data suggests the following analysis: labor turnover costs, such as modeled by the EPL index, appear to be the most important labor market institution explaining the differences in output volatility in the eurozone. Indeed, in all the specifications of our model, EPL is statistically significant, and has a significant economic impact, higher EPL being correlated with lower volatility. Replacement rates seem to have a (positive) impact on output volatility, even though it is weaker and depends in a stronger way on interaction effects. Overall, the empirical results are in line with our theoretical analysis.

\subsubsection{Inflation Volatility}

For inflation volatility, we estimate a model of the following form:

$$
V I C_{i}=\beta_{0}+\beta_{1} L T C_{i}+\beta_{2} R R_{i}+\beta_{3}\left(L T C_{i} * R R_{i}\right)+\beta_{4} \text { Control }_{i}+\varepsilon_{i} .
$$

We use the same step-down regression procedure as in 4.2.2. As seen in Table 6, there are two control variables that show some significance, but because of the limited sample, we do not integrate both into the estimated equations. As volatility of government expenditure (VGE) is most significant individually, and dominates average growth in a joint regression ${ }^{33}$, we choose to use only this control variable. The results for a linear specification are shown in Table 8 .

\footnotetext{
${ }^{33}$ When estimating the model $V I C_{i}=\beta_{0}+\beta_{1} G R O W T H_{i}+\beta_{2} V G E_{i}+\varepsilon_{i}$, only VGE is significant (at a $10 \%$ level).
} 
Table 8: Inflation Volatility: Linear Results

\begin{tabular}{|l|l|c|c|}
\hline & & Model 1 & Model 2 \\
\hline & Constant & -0.042 & $3.323^{* *}$ \\
\hline LTC & EPL & (dropped) & $-1.293^{* *}$ \\
\hline RR & NRR & (dropped) & \\
\hline & GRR & & $-9.567^{* *}$ \\
\hline Interaction & EPL*NRR & (dropped) & \\
\hline & EPL*GRR & & $3.613^{* *}$ \\
\hline Control & VGE & $0.350^{* * *}$ & $0.380^{* * *}$ \\
\hline & $\mathrm{R}^{2}$ & 0.60 & 0.82 \\
\hline & $\mathrm{R}^{2}($ adj) & 0.55 & 0.70 \\
\hline & F-Stat. & $13.33^{* * *}$ & $6.92^{* *}$ \\
\hline
\end{tabular}

Explanations: ${ }^{* * *}$ significant at $1 \%,{ }^{* *}$ significant at $5 \%,{ }^{*}$ significant at $10 \%$.

The results depend on the model that is used: when considering the NRR for measuring replacement rates, all labor market variables drop out of the regressions, and we only find a significant positive correlation between inflation volatility and the volatility of government expenditure. When using the GRR, however, the labor market variables seem to matter, and their impact depends in a strong way on interaction effects, the impact of EPL and GRR being positive or negative according to the values of the respective other indicator. The only constant finding in these estimations is that governments spending rules (or shocks) seem to matter, as theory would also predict. ${ }^{34}$

Table 9: Inflation Volatility: Nonlinear Results

\begin{tabular}{|l|l|c|c|}
\hline & & Model 1 & Model 2 \\
\hline & Constant & 0.172 & 0.172 \\
\hline LTC & $1 / \mathrm{EPL}$ & (dropped) & (dropped) \\
\hline RR & $1 / \mathrm{NRR}$ & (dropped) & \\
\hline & $1 / \mathrm{GRR}$ & & (dropped) \\
\hline Interaction & $1 / \mathrm{EPL}^{*} 1 / \mathrm{NRR}$ & (dropped) & \\
\hline & $1 / \mathrm{EPL}^{*} 1 / \mathrm{GRR}$ & & (dropped) \\
\hline Control & $\mathrm{VGE}^{\wedge} 2$ & $0.121^{* * *}$ & $0.121^{* * *}$ \\
\hline & $\mathrm{R}^{2}$ & 0.62 & 0.62 \\
\hline & $\mathrm{R}^{2}(\mathrm{adj})$ & 0.58 & 0.58 \\
\hline & $\mathrm{F}^{*}$ Stat. & $14.81^{* * *}$ & $14.81^{* * *}$ \\
\hline
\end{tabular}

Explanations: ${ }^{* * *}$ significant at $1 \%,{ }^{* *}$ significant at $5 \%, *$ significant at $10 \%$.

In sum, our empirical results do not permit to conclude on the relationship between labor market variables and inflation volatility. They only indicate that government spending shocks seem to be a decisive feature. All these findings can be rationalized by our theoretical model.

\section{Theory, Empirics and Open Questions}

The empirical analysis confirms the theoretical prediction that larger firing costs are associated with lower output volatilities, while larger replacement rates are associated with higher output

\footnotetext{
${ }^{34}$ See Rother (2004) for the effect of government spending on inflation volatility. The same would be true if we integrated government spending shocks into our model.
} 
volatilities. The empirical analysis is inconclusive with respect to the role of firing costs and the replacement rate on inflation volatility. This can be rationalized by the theoretical analysis when both aggregate and supply shocks contribute substantially to business cycle fluctuations. ${ }^{35}$

Our analysis has the following implications:

- Interestingly, the standard search and matching model does not necessarily predict the same qualitative effect of higher labor turnover cost on output volatility. Silva and Toledo (2009, p. 93-94) "argue that introducing post-match labor turnover costs in the standard DMP [Diamond-Mortensen-Pissarides] matching model with endogenous job destruction helps increase the labor market volatility in response to labor productivity shocks of reasonable magnitude." Obviously, this prediction from the DMP model would stand in contrast to what we found in the eurozone data, and the question why our model and the DMP model generate different predictions needs further investigation.

- The empirical part point towards some nonlinearities and interactions in the correlation between labor market institutions and macroeconomic volatilities. However, currently we are unable to map them into our model, as the OECD employment protection legislation numbers are indices, but not the actual costs of firing a worker (as in the model). Current attempts of the OECD to calculate actual firing cost numbers may allow to move further into this direction.

- As monetary policy may have a substantial effect on macroeconomic volatilities, we have chosen the eurozone as a natural experiment to be studied. Theory confirms that we can expect substantial volatility differences due to monetary policy. And our first glance at the data reconfirms this. We have done a correlation analysis for the entire set of OECD countries. The correlation between labor market institutions and output volatility seems to be a lot less significant and stable than within the eurozone. ${ }^{36}$ Only further econometric research can shed more light on the role of monetary policy for macroeconomic volatilities.

- As firing costs and replacement rates seem to be important for the propagation of macroeconomic shocks, they should be taken into account in quantitative business cycle analysis; particularly when these labor market institutions are important, such as in European countries. Up to now, the estimated workhorse medium-scale New Keynesian models assume frictionless labor markets without unemployment (see, e.g., Smets and Wouters, 2003, 2007) and thereby ignore the potentially interaction between labor market institutions and the business cycle. The integration into more detailed models (e.g., multi-country model) may deliver further insights.

- Labor market institutions drive a wedge between the first best outcome and the actual outcome. If this wedge is of quantitative importance, these institutions lead to a substantially distorted equilibrium. As the expected qualitative correlation between unemployment benefits/firing costs and output volatility seems to be of quantitative importance in the data, we can expect that these institutions are actually welfare relevant for various policies (e.g., monetary and fiscal policy). So far, there is only little theoretical research on these issues (for one exception, see Faia et al., 2009). Asymmetric reactions to symmetric shocks imply welfare costs within a monetary union. Only further theoretical work can provide insights on this issue.

\section{Conclusion}

This paper shows theoretically and empirically that labor turnover costs and replacement rates matter for output volatilities within the eurozone. The former has a dampening effect, while the latter increases output volatility. Although the empirical results are based on a small dataset, they offer first insights into how heterogeneous labor market institutions act in a

\footnotetext{
${ }^{35}$ This would be in line with Smets and Wouters (2003) where both aggregate supply and demand shocks play a role in driving the European business cycle.

${ }^{36}$ Rumler and Scharler's (2009) paper points exactly into the same direction. They write that employment protection legislation appear to play a limited role for output volatility.
} 
monetary union. This has important implications for the ability of labor market models to replicate macroeconomic volatilities and for the type of labor market institutions that should be integrated into business cycle models. 


\section{References}

Abbritti, M., Mueller, A., 2007. Asymmetric labor market institutions in the EMU: positive and normative implications. Economics Working Paper 37, Department of Economics, Central Bank of Iceland.

Abbritti, M., Weber, S., 2008. Labor market rigidities and the business cycle: price vs. quantity restricting institutions. HEI Working Papers, No. 1-2008, The Graduate Institute for International Studies.

Beck, T., Lundberg, M., Majnoni, G., 2006. Financial intermediary development and growth volatility: Do intermediaries dampen or magnify shocks? Journal of International Money and Finance, 25 (7), 1146-1167.

Benalal, N., Diaz del Hoyo, J.L., Pierluigi, B., Vidalis, N., 2006. Output growth differentials across the Euro area countries. Some stylized facts. Occasional Paper Series 45, European Central Bank.

Bentolila, S., Bertola, G., 1990. Firing costs and labour demand: How bad is eurosclerosis. Review of Economic Studies, 57, 381-402.

Bertola, G., Koeniger, W., 2007. Consumption smoothing and income redistribution. European Economic Review, 51 (8), 1941-1958.

Blanchard, O., and Galí, J., 2010. Labor markets and monetary policy: a new Keynesian model with unemployment. American Economic Journal - Macroeconomics, forthcoming.

Blanchard, O., Galí, J., 2007. The macroeconomic effects of oil shocks: Why are the 2000s so different from the 1970s? NBER Working Paper 13368, National Bureau of Economic Research Inc.

Blanchard, O., Wolfers, J., 2000. The role of shocks and institutions in the rise of European unemployment: The aggregate evidence. Economic Journal, Royal Economic Society, 110 (462), C1-33.

Botero, J., Djankov, S., Porta, R., Lopez-De-Silanes, F., 2004. The regulation of labor. The Quarterly Journal of Economics, 119 (4), 1339-1382.

Campolmi, A., Faia, E., 2010. Cyclical inflation divergence and different labor market institutions in the EMU. Journal of Economic Dynamics and Control, forthcoming.

Chen, Y.-F., Funke, M., 2009. Threshold effects of dismissal protection regulation and the emergence of temporary work agencies. Studies in Nonlinear Dynamics \& Econometrics, $13(4), 1-27$.

Chen, Y.-F., Funke, M., 2005. Non-wage labour costs, policy uncertainty and labour demand: a theoretical assessment. Scottish Journal of Political Economc, 52 (5), 687-709.

Costain, J. S., Reiter, M., 2008. Business cycles, unemployment insurance, and the calibration of matching models. Journal of Economic Dynamics and Control, 32 (4), 1120-1155.

de la Croix, D., de Walque, G., Wouters, R., 2007. Dynamics and monetary policy in a fair wage model of the business cycle. European Central Bank Working Paper, No. 780. 
Dhont, T., Heylen, F., 2008, Why do Europeans work (much) less? It is taxes and government spending. Economic Inquiry, Western Economic Association International, 46 (2), 197207.

Eurostat, 2008. Eurostat internet database. Available online at http://ec.europa.eu/eurostat. Eurostat, Luxembourg.

Faia, E., 2009. Ramsey monetary policy with labor market frictions. Journal of Monetary Economics, 56(4), 570-581.

Faia, E., Lechthaler, W., Merkl, C., 2009. Labor turnover costs, workers' heterogeneity and optimal monetary policy. IZA Discussion Paper, No. 4322.

Gartner, H., Merkl, C., Rothe, T., 2009. They are even larger! More (on) puzzling labor market volatilities. IZA Discussion Paper, No. 4403.

Grüner, H. P., 2010. Why EMU is not a failure. European Journal of Political Economy, 26, $1-11$.

Hagedorn, M., Manovskii, I., 2008. The cyclical behavior of equilibrium unemployment and vacancies revisited. American Economic Review, American Economic Association, 98 (4), 1692-1706.

Hall, R., 2005. Employment fluctuations with equilibrium wage stickiness. American Economic Review, American Economic Association, 95 (1), 50-65.

IMF, 2008. International Financial Statistics, Issue 10/2008. International Monetary Fund, Washington.

Klomp, J., de Haan, J., 2009, Political institutions and economic volatility. European Journal of Political Economy, 25, 311-326.

Krause, M. U., Lubik, T. A., 2007. The (ir)relevance of real wage rigidity in the new Keynesian model with search frictions. Journal of Monetary Economics, 54 (3), 706-727.

Lechthaler, W., Merkl, C., Snower, D., 2010. Monetary persistence and the labor market: a new perspective. Journal of Economic Dynamics and Control, 34 (5), 968-983.

OECD, 1999. OECD Employment Outlook 1999. Organization for Economic Co-operation and Development, Paris.

OECD, 2004. OECD Employment Outlook 2004. Organization for Economic Co-operation and Development, Paris.

OECD, 2007. Benefits and wages: OECD indicators 2007. Organization for Economic Cooperation and Development, Paris.

Pissarides, C. A., 2000. Equilibrium unemployment theory. Cambridge, MA: MIT Press.

Reyneri, E., 1994. Italy: a long wait in the shelter of the family and of safeguards from the State. In Benoit-Guilbot, O., Gallie, D. (Eds.), Long-Term unemployment. Pinter, London, pp. 97-110.

Rother, P., 2004. Fiscal policy and inflation volatility. Working Paper Series 317, European Central Bank. 
Rumler, F., Scharler, J., 2009. Labor market institutions and macroeconomic volatilities in a panel of OECD countries. Working Paper Series 1005, European Central Bank.

Shimer, R., 2005. The cyclical behavior of equilibrium unemployment and vacancies. American Economic Review, 95 (1), 25-49.

Silva, J. I., Toledo, M., 2009. Labor turnover costs and the cyclical behavior of vacancies and unemployment. Macroeconomic Dynamics, 13 (S1), 76-96.

Smets, F., Wouters, R., 2005. Comparing shocks and frictions in US and Euro area business cycles: a bayesian DSGE approach. Journal of Applied Econometrics, 20 (2), 161-183.

Smets, F., Wouters, R., 2007. Shock and frictions in US business cycles: a bayesian DSGE approach. American Economic Review, 97 (3), 586-606.

Snower, D., Merkl, C., 2006. The caring hand that cripples: The East German labor market after reunification, American Economic Review, 96(2), 375-382.

Taylor, J. B., 1993. Discretion versus policy rules in practice. Carnegie Rochester Conference Series on Public Policy, 39, 195-214.

Wilke, R., 2005. New estimates of the duration and risk of unemployment for West-Germany. Journal of Applied Social Science Studies, Verlag Duncker \& Humblot, Berlin, 125(2), 207-237.

World Bank, 2008. Doing Business 2009. The World Bank Group, Washington. 


\section{Technical Appendix}

\subsection{Theoretical Model}

The model consists of the following equations:

$$
\begin{aligned}
& \frac{1}{C_{t}^{\sigma}}=\beta E_{t}\left[\left(\frac{P_{t}}{P_{t+1}}\right)\left(1+i_{t}\right)\left(\frac{1}{C_{t+1}^{\sigma}}\right)\right] \\
& W_{t} / P_{t}=\gamma\left(A_{t} M C_{t}-\varepsilon_{t}^{I}\right)+(1-\gamma) B \\
& H=A_{t} M C_{t}-W_{t} / P_{t}-v_{h, t}+E_{t}\left(\Delta_{t, t+1} \tilde{\Pi}_{I, t+1}\right), \\
& \eta_{t}=\Gamma\left(v_{h, t}\right) \text {, } \\
& -F=A_{t} M C_{t}-W_{t} / P_{t}-v_{f, t}+E_{t}\left(\Delta_{t, t+1} \tilde{\Pi}_{I, t+1}\right), \\
& \phi_{t}=1-\Gamma\left(v_{f, t}\right) \text {, } \\
& E_{t}\left(\Delta_{t, t+1} \tilde{\Pi}_{I, t+1}\right)=E_{t}\left(\begin{array}{c}
\Delta_{t, t+1}\left(1-\phi_{t+1}\right)\left(M C_{t+1} A_{t+1}-W_{t+1} / P_{t+1}-E_{t}\left(\varepsilon_{t+1} \mid 1-\phi_{t+1}\right)\right) \\
+\Delta_{t, t+1}\left(1-\phi_{t+1}\right) \Delta_{t+1, t+2} E_{t+1}\left(\tilde{\Pi}_{I, t+2}\right)-\Delta_{t, t+1} \phi_{t+1} F
\end{array}\right), \\
& n_{t}=n_{t-1}\left(1-\phi_{t}-\eta_{t}\right)+\eta_{t} \\
& \Xi_{t}^{e}=\frac{\int_{-\infty}^{v_{h}} \epsilon_{t} f\left(\epsilon_{t}\right) d \epsilon_{t}}{\eta_{t}} \\
& \Xi_{t}^{i}=\frac{\int_{-\infty}^{v_{f}} \epsilon_{t} f\left(\epsilon_{t}\right) d \epsilon_{t}}{1-\phi_{t}} \\
& 0=(1-\varepsilon)+\varepsilon p_{z, t}-\Psi\left(\pi_{t}-\bar{\pi}\right) \pi_{t} \\
& +E_{t}\left\{\Delta_{t, t+1} \Psi\left(\pi_{t+1}-\bar{\pi}\right) \frac{Y_{t+1}}{Y_{t}} \pi_{t+1}\right\}, \\
& C_{t}=Y_{t}-n_{t-1} \phi_{t} F-\left(1-n_{t-1}\right) \eta_{t} H-\left(1-\phi_{t}\right) n_{t-1} \Xi_{t}^{i}-\left(1-n_{t-1}\right) \eta_{t} \Xi_{t}^{e}, \\
& n_{t} A_{t}=Y_{t}, \\
& \left(\frac{1+i_{t}}{1+\bar{\imath}}\right)=\left(\frac{\pi_{t}}{\bar{\pi}}\right)^{\alpha_{\pi}} e^{\varkappa t} \\
& A_{t}=A^{1-\rho_{a}} A_{t-1}^{\rho_{a}} e^{\mu_{t}} .
\end{aligned}
$$




\subsection{Empirical Details}

\subsubsection{Macroeconomic Variables}

There are two breaks in the IFS time series for real GDP and the GDP deflator. In Austria, a break in the first quarter of 2000 is notified in the database. In Belgium, there is no such indication, but in the first quarter of 2008, the time series evolve in a peculiar way (quarterly growth rate of over $13 \%$, quarterly deflation rate of $9 \%$ ) that is not matched by other data sources. Because of these breaks, our Austrian time series does not begin until the first quarter of 2000, and the Belgian one stops in the fourth quarter of 2007. Additionally, some countries did not report data for all the quarters of the observation period: thus, the year 1999 is missing for Greece, the second quarter of 2008 is missing for Portugal and the Dutch GDP Deflator, and the two first quarters of 2008 are missing for Ireland.

\subsubsection{Labor Market Institutions}

For the computation of the OECD's EPL index, the sub-indicator for the regulation of individual dismissals takes into account the associated procedural inconveniences, notice periods and severance pay for workers with a different number of years of service, and their possibilities for contesting dismissal and obtaining compensation and reinstatement. Collective dismissals are assessed by the scope of their legal definition and the additional requirements and costs they cause for employers. Finally, regulation of temporary contracts is measured by the range of jobs for which such contracts are legal, the restrictions on their renewal and their maximum cumulated duration ${ }^{37}$. Further information on the EPL indicators can be found in OECD (1999), where the index was first established.

Because it covers a large number of relevant aspects, the NRR appears to be the best indicator of the generosity of unemployment benefits. Nevertheless, Italy seems to be an outlier with this measure: even when including social assistance, replacement rates are extremely low (only $5.4 \%$ in 2003, driven by the long-term unemployed, who according to the OECD do not receive benefits at all). There is some evidence, laid out for example in Dhont and Heylen $(2008)^{38}$ that this figure does not capture the entire nature of the Italian social protection system. Thus, this is an additional reason for using the GRR as a robustness control. However, as results for the NRR and the GRR, at least in a model with several explaining variables, are very similar, the Italian case does not affect our main conclusions.

\footnotetext{
${ }^{37}$ The associated weights are 5/12 for protection against individual dismissals and regulation of temporary employment, and 1/6 for protection against collective dismissals.

${ }^{38}$ Dhont and Heylen point out that "the gap between Italy and the other European countries is much smaller than it seems. Although unemployment benefits barely exist in Italy, this does not imply a zero fall-back position. Reyneri (1994) points to the importance of family support as an alternative to unemployment benefits. Furthermore, he emphasizes the existence of invalidity benefits as an additional mechanism of public transfers that the unemployed could receive."
} 


\subsubsection{Control Variables}

\begin{tabular}{|c|c|c|}
\hline Variable & Computation & Source \\
\hline $\begin{array}{l}\text { Av erage quarterly } \\
\text { grow th rate } \\
\text { (GROWTH) }\end{array}$ & $\begin{array}{l}\text { Simple average of the quarterly growth } \\
\text { rates of real GDP, over the observation } \\
\text { period. }\end{array}$ & $\begin{array}{l}\text { IFS, Issue } 10 / 2008 \text { (i.e., the } \\
\text { same series used to compute } \\
\text { output volatility) }\end{array}$ \\
\hline $\begin{array}{l}\text { Av erage quarterly } \\
\text { inflation rate } \\
\text { (MEAN_INFL) }\end{array}$ & $\begin{array}{l}\text { Simple average of the quarterly inflation } \\
\text { rates, over the observ ation period. }\end{array}$ & $\begin{array}{l}\text { IFS, Issue } 10 / 2008 \text { (i.e., the } \\
\text { same series used to compute } \\
\text { inflation volatility) }\end{array}$ \\
\hline $\begin{array}{l}\text { Average real GDP } \\
\text { (GDP) }\end{array}$ & $\begin{array}{l}\text { Simple average of the yearly real GDP, } \\
\text { in US dollars and constant PPP, over the } \\
\text { observation period. (1999-2007, except } \\
\text { for Austria and Greece, where the } \\
\text { observation period is } 2000-2007 \text { ) }\end{array}$ & $\begin{array}{l}\text { OECD (2008) (As the IFS } \\
\text { figures are indexed to } 100 \text {, } \\
\text { they could not be used as } \\
\text { size indicators) }\end{array}$ \\
\hline $\begin{array}{l}\text { Average GDP per } \\
\text { capita (GDPPC) }\end{array}$ & $\begin{array}{l}\text { Simple average of the yearly GDP per } \\
\text { capita, in US dollars and constant PPP, } \\
\text { ov er the observation period. }\end{array}$ & OECD (2008) \\
\hline $\begin{array}{l}\text { Volatility of } \\
\text { Government } \\
\text { Expenditure } \\
\text { (VGE) }\end{array}$ & $\begin{array}{l}\text { Standard dev iation of a "govemment } \\
\text { expenditure gap," computed similarly to } \\
\text { the output gap. Quarterly government } \\
\text { expenditure is defined as the ratio real } \\
\text { government expenditure/real GDP. } \\
\text { The data covers the period from the first } \\
\text { quarter of } 1999 \text { to the second quarter of } \\
2008 \text { and is seasonally adjusted. Two } \\
\text { breaks (Ireland, first quarter } 2000 \text {, and } \\
\text { Austria, first quarter 2008) are left out. }\end{array}$ & $\begin{array}{l}\text { Eurostat (2008), Quarterly } \\
\text { National Accounts }\end{array}$ \\
\hline $\begin{array}{l}\text { Volatility of Terms } \\
\text { of Trade } \\
\text { (VOLTOT) }\end{array}$ & $\begin{array}{l}\text { Standard dev iation of a "terms of trade } \\
\text { gap", computed similarly to the output } \\
\text { gap. Quarterly terms of trade are defined } \\
\text { as the ratio between the deflator for } \\
\text { exports and the deflator for imports of } \\
\text { goods and services. Figures are } \\
\text { seasonally adjusted and indexed to } 100 \\
\text { in } 2000 \text {. } \\
\text { Data missing for Austria and Greece. }\end{array}$ & OECD (2009a) \\
\hline $\begin{array}{l}\text { Volatility of } \\
\text { Import Prices } \\
\text { (VOLIMP) }\end{array}$ & $\begin{array}{l}\text { Standard dev iation of the cyclical } \\
\text { component of imp ort prices. Quarterly } \\
\text { import prices were calculated using the } \\
\text { deflator for imports of goods and } \\
\text { services, (seasonally adjusted, indexed } \\
\text { to } 100 \text { in } 2000 \text { ) and detrended using a } \\
\text { HP Filter, with } \lambda=1,600 \text {. } \\
\text { Data missing for Austria and Greece. }\end{array}$ & OECD (2009a) \\
\hline $\begin{array}{l}\text { Union Density } \\
\text { (UNDENS) }\end{array}$ & $\begin{array}{l}\text { Ratio of Union Membership relative to } \\
\text { Total Employment, in } 2001 \text { (latest time } \\
\text { point available for all Eurozone } \\
\text { Countries). }\end{array}$ & OECD (2009b) \\
\hline $\begin{array}{l}\text { Wage-Setting } \\
\text { Coordination } \\
\text { (WSCOORD) }\end{array}$ & $\begin{array}{l}\text { Index established by the OECD, } \\
\text { increasing in the degree of coordination } \\
\text { of wage negotiations. The exact } \\
\text { definition and scales can be found in } \\
O E C D(2004) \text {. }\end{array}$ & OECD (2004) \\
\hline
\end{tabular}

